\title{
Liberating possibilities of a new identity: A review of Christi van der Westhuizen's Sitting Pretty: White Afrikaans Women in Postapartheid South Africa
}

\begin{tabular}{|c|c|}
\hline $\begin{array}{l}\text { Author: } \\
\text { Tanya van Wy }\end{array}$ & $K^{1}$ (D) \\
\hline $\begin{array}{l}\text { Affiliation: } \\
\text { 1Department } \\
\text { and Historical } \\
\text { Faculty of The } \\
\text { Religion, Univ } \\
\text { Pretoria, Sout }\end{array}$ & $\begin{array}{l}\text { f Systematic } \\
\text { Theology, } \\
\text { ology and } \\
\text { ersity of } \\
\text { n Africa }\end{array}$ \\
\hline $\begin{array}{l}\text { Research Proj } \\
\text { Project Leade } \\
\text { Project Numb }\end{array}$ & $\begin{array}{l}\text { ect Details: } \\
\text { r: T. van Wyk } \\
\text { er: } 22153145\end{array}$ \\
\hline $\begin{array}{l}\text { Project Descri } \\
\text { This research } \\
\text { research proje } \\
\text { Theology, dire } \\
\text { Dr Tanya van } \\
\text { of Theology ar } \\
\text { University of }\end{array}$ & $\begin{array}{l}\text { ption: } \\
\text { s part of the } \\
\text { ct, Political } \\
\text { cted by } \\
\text { Nyk, Faculty } \\
\text { d Religion, } \\
\text { retoria. }\end{array}$ \\
\hline $\begin{array}{l}\text { Correspondin } \\
\text { Tanya van Wyl } \\
\text { tanya.vanwyk }\end{array}$ & $\begin{array}{l}\text { g author: } \\
\text { @up.ac.za }\end{array}$ \\
\hline $\begin{array}{l}\text { Dates: } \\
\text { Received: } 10 \mathrm{~A} \\
\text { Accepted: } 10 \\
\text { Published: } 11\end{array}$ & $\begin{array}{l}\text { Aug. } 2018 \\
\text { Aug. } 2018 \\
\text { Sept. } 2018\end{array}$ \\
\hline $\begin{array}{l}\text { How to cite th } \\
\text { Van Wyk, T., } 2 \\
\text { possibilities of } \\
\text { A review of Ch } \\
\text { Westhuizen's S } \\
\text { White Afrikaar } \\
\text { Postapartheid } \\
\text { HTS Teologiese } \\
\text { Theological St } \\
\text { a5220. https:/ } \\
\text { 10.4102/hts.v }\end{array}$ & $\begin{array}{l}\text { is article: } \\
\text { O18, 'Liberating } \\
\text { a new identity: } \\
\text { risti van der } \\
\text { itting Pretty: } \\
\text { רs Women in } \\
\text { South Africa', } \\
\text { Studies/ } \\
\text { udies } 74(4) \text {, } \\
\text { /doi.org/ } \\
44.5220\end{array}$ \\
\hline $\begin{array}{l}\text { Copyright: } \\
\text { C 2018. The A } \\
\text { Licensee: AOSI } \\
\text { is licensed und } \\
\text { Creative Comm } \\
\text { Attribution Lic }\end{array}$ & $\begin{array}{l}\text { uthors. } \\
\text { S. This work } \\
\text { ler the } \\
\text { nons } \\
\text { ense. }\end{array}$ \\
\hline 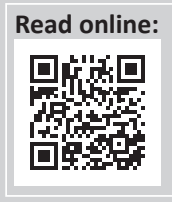 & $\begin{array}{l}\text { Scan this QR } \\
\text { code with your } \\
\text { smart phone or } \\
\text { mobile device } \\
\text { to read online. }\end{array}$ \\
\hline
\end{tabular}

\section{Author:}

\section{Affiliation:}

${ }^{1}$ Department of Systematic Faculty of Theology and Religion, University of Pretoria, South Africa Project Leader: T. van Wyk

Project Description: This research is part of the Theology, directed by Dr Tanya van Wyk, Faculty of Theology and Religion,

Corresponding author: Tanya van Wyk,

Dates: Published: 11 Sept. 2018

How to cite this article: Van Wyk, T., 2018, 'Liberating A review of Christi van der Westhuizen's Sitting Pretty: HTS Teologiese Studies/ eological Studies 74(4), a5220. https://doi.org/ 102/hts.v74i4.5220

Licensee: AOSIS. This work is licensed under the Creative Commons Attribution License.

\begin{abstract}
In this article, Christi van der Westhuizen's sociopolitical contribution in her publication, Sitting Pretty: White Afrikaans Women in Postapartheid South Africa, is reviewed. In light of the official end of apartheid in 1994, South Africans are attempting to define a new identity. Van der Westhuizen's publication focusses on how the identity of white Afrikaans women, as both the oppressor and the oppressed, influences and contributes to the endeavour of a search for new identity. In deconstructing and re-imagining new identity, Van der Westhuizen deconstructs the 'supporting scaffolding' of Afrikaner identity and examines the impact of white patriarchal hegemony that silences the voice of women, sexual minorities and black consciousness. The review concludes with the emphasis on the transformative role of shame, that is, the willingness to expose the false sense of goodness that we had of ourselves, as pointed out by Van der Westhuizen. In this regard, the recognition of the intersectionality of people's experiences becomes a key aspect of the endeavour of a search for new identity.
\end{abstract}

\section{Introduction: Trying to construct a new identity}

For more than 20 years after the official end of apartheid (1994), South Africans have been busy with the business of trying to figure out who we are. According to Christi van der Westhuizen, Nelson Mandela initiated this endeavour during his inaugural 'State of the Nation' address as the new South African president, when he stated that 'our endeavours must be about the liberation of the woman, the emancipation of the man and the liberty of the child'. ${ }^{1}$ Mandela made an invitation to the possibilities of new identification and extended this invitation to include a specific group, namely 'South Africans who identify as "Afrikaner women"' (Van der Westhuizen 2017:1).

As part of the Afrikaner identity that is undergoing a type of 'rehabilitation' in light of postapartheid, Christi van der Westhuizen (2017) focusses on the identity of the white Afrikaans women:

Including femininity as one of the objects in this study, constructed as other in relation to hegemonic masculinity, allows an unpicking of the strands of othering internal to Afrikaner identity. It allows for an investigation of subjects occupying the dual position of both oppressors and oppressed: these subjects were advantaged by Afrikaner nationalism and apartheid, but simultaneously were radically undermined by gender subjugation. Including femininity provides the possibility of uncovering dissidence amid conformism. This book ... can be drawn upon to examine the specificities of the co-construction of postapartheid identities. (p. 17)

Van der Westhuizen's 2017 publication, Sitting Pretty: White Afrikaans Women in Postapartheid South Africa, is an exploration of the extent to which Mandela's invitation to a new identity has been taken up by these women. This review assesses this sociopolitical contribution to the 'identity-question' of Afrikaans women, as part of the search for identity within Afrikaans and South African society. It can be stated, therefore, that Van der Westhuizen's work essence is about identity: how it is created, how it is constructed, what governs it, how identity can collapse, how it is threatened, how it is challenged and above all how it can be reconstructed. With this in mind, themes and aspects of her contribution are discussed in different sections of this article.

1.http://www.sahistory.org.za/article/stat-nation-address-president-south-africa-nelson-mandela (as referenced by Van der Westhuizen 2017:1). 


\section{A panopticon of heteronormative discourse and the formation of heteronormative identity}

In deconstructing and re-imagining new identity, Van der Westhuizen deconstructs the 'supporting scaffolding' of Afrikaner identity and examines the impact of white patriarchal hegemony that silences the voice of women, sexual minorities and black consciousness. Her life history research utilised in the book is based on the subjectification and objectification of women that she illustrates by way of a sociological construction of the so-called Sarielese - a readership of the Afrikaans magazine Sarie, with a dominant male editorship retaining a pre-1994 apartheid and nationalist ideology. During her 2018 keynote address at the annual meeting of the Society for Practical Theology in South Africa, Yolanda Dreyer emphasised the sociopolitical contribution of Van der Westhuizen in reference to role of the media in constructing and contributing towards what is understood as 'normal' and 'natural'. This, in turn, contributes to forming people's social identity. Dreyer recounts about Sarie: 'When I was a child, the husband of a friend of my mother's was the editor of Sarie. I remember thinking: what would this man know about the woman's stuff in the magazine of which he was the boss. That was in the 1960s when, in my frame of reference, every boss was necessarily male. Even so, it seemed strange to me'.

This type of discourse is an illustration and manifestation of heteronormativity, which is for Van der Westhuizen (2016) 'a bedrock of the white Afrikaans enclave:'

The internal economy of differences in the Afrikaner neonationalist enclave is as highly hierarchical as its external division of differences, and reflects the external division in ways that draw on colonial intersectionalities. The institutions of commerce and religion serve as spaces to iterate and validate particularist practices of race, gender, sexuality, and class. Sometimes commerce and religion conflate to reproduce these practices and associated identity formations. (p. 7 of 9)

Heteronormativity is the conviction that there are designated roles and spaces and therefore identities for people based on a binary understanding (either-or) and categorisation of gender, ethnicity and sexuality (cf. Dreyer 2006; 2007). It leads to 'societal expectations' of so-called normal patterns of life. This type of heteronormative identity is constructed in a 'panopticon' fashion.

According to the philosopher Michel Foucault (1991:212), panopticism is a micropower that classifies, hierarchises, validates and invalidates (cf. Van der Westhuizen 2016:7 of 9). The notion 'panopticon' refers to a structure (or process) of unseen surveillance, which conveys omnipresent and omniscient power and enforces this power by convincing the objects of this structure (or: people taken up into the cogs of its machinery) to mutually enforce this surveillance because they experience the effects of it. This notion is based on a design by Jeremy Bentham in 1791 for an actual panopticon - a prison. In this prison, a centrally located guard in a central watchtower in a circular building observes the prisoners simultaneously. The prisoners know (or are almost certain) that they are being watched, but they cannot see who is watching them - the control from the 'institutional heart' of the space is invisible. This 'inequity in gaze' creates the sentiment that the prisoners are being watched all the time, causing them to modify their behaviour accordingly and to internalise the surveillance and to start policing each other in the same way that they experience themselves to be surveilled (Bentham 1995:29-95; cf. Van Aarde 2012:4 of 11; Wezner 2012:149). Because of the very fact that 'subjects' are constantly aware of this, albeit the invisible panoptical societal structure, subjects are able to police themselves (Bentham's [1995] original intention). This process which starts with 'observation' (subjects are aware that they are being observed) and leads to 'control' (subjects being aware that the observation's function is control), leads to subjects further conforming to the observation or control and then being 'normalised' and by then 'examining' themselves according to and on the grounds of the 'norm'. Foucault used 'panopticon' as broad metaphor, to refer to modernity which imperceptibly regulates people's lives in a heteronormative way: mad versus normal, sick versus healthy and homosexual versus heterosexual (cf. Van Wyk 2014:3-4 of 7). Foucault exposes the patterns of power in historical and contemporary societies. Power reifies people by objectifying people, which is to subjectify people. A person becomes an object in relation to someone else because of firstly, being controlled by someone else and being made reliant on that person. Secondly, a person becomes an object in relation to someone else because as an 'object' a person becomes fixed to the identity assigned to you as your identity on your behalf. Within the panopticon - and because of an amount of self-knowledge - all of this happens while you are fully aware of it taking place.

As is emphasised by Van der Westhuizen in Sitting Pretty, a person becomes embodied in those patterns of life which they are subjected to as an object - others become the judge of your thoughts and practices. This is the process of objectifying and forms the context for the contemporary Western way of governance. In a 'panoptical' manner, the objectifying does not visibly manifest as governance by way of violence or coercive power that is visible in violent or explicit tactics of coercive acts. Rather it manifests in the creation and then the perpetuation (constitution) of government and the exercise of discipline by government to the extent that a person lets himself or herself be governed by this process.

\section{Identity, intersectionality and heterotopia}

It is to this panopticon-constructed identity that Van der Westhuizen speaks in Sitting Pretty. It is the awareness of the influence of identity that is constructed this way that should lead to the deconstruction of said identity and aid South Africans in taking necessary steps on the path to an 
identity that is based on the acknowledgement of intersectionality - the way in which different experiences and levels of oppression and forced identity formation intersect. The emphasis and acknowledgement of intersectionality is a necessary step in taking up the invitation of a new identification: for white Afrikaans women, for a new Afrikaner identity and a new South African identity. Interestingly, and Van der Westhuizen does not refer to this, one of Foucault's other concepts might offer the possibility for a space of intersectionality: heterotopia. This 'space' offers the possibility to transcend the remnants of binary thinking. This is against the background of Henry Lefebvre's ([1974] 1991:26) understanding of 'space' as 'a social product' and a category of existential experience. 'Heterotopia' is an epistemological insight of Foucault ([1967] 1984) and was coined by him in a lecture in 1967 in reference to 'space' as place of representation; 'utopia' as 'space' of the future and fantasy as 'space' that has been sacralised. Foucault endorses the concept 'utopia', but very decisively distinguishes between 'heterotopia' and 'utopia'. 'Heterotopias' are not 'fantasy islands'. Heterotopias are spaces, literally 'other places' that exist. But it is a space of contrast (cf. Foucault [1967] 1984), because heterotopian space is not devoid of utopian ideals - that is, it is not antiutopian. Rather it is a space wherein utopia becomes visible and tangible, real and traceable. It is a space of tension with regard to expectation and realisation. The point is that heterotopia denotes a way of seeing and knowing (epistemology), which in turns influences being (ontology)the space itself; a space that exists, or rather portrays that things can be different. Not only a space wherein the dream of 'other than the norm' is dreamt - that too. Heterotopia is a space where 'other seeing' is 'other being' - other doing. A space where unity is not threatened, but rather strengthened, by diversity (cf. Van Wyk 2014:4-5 of 7).

\section{Conclusion: Shame as a power to transform}

Van der Westhuizen's work emphasises that it is necessary to make a shift from thinking about the other as worthless to thinking of the other as a human being, a person of equal value. It requires the willingness to expose the false sense of goodness that we had of ourselves. It requires the courage to see what is going on and to condemn it as unconscionable, to take responsibility for our complicity in it, to be willing to feel the shame, for shame has the power to transform (Dreyer, keynote address, 2018).

The book is an example of transdisciplinary scholarly work, as it makes use of critical feminist theory and postmodern epistemology, based on in-depth life history research and narrative techniques. It is of significance for the current South African cultural master narrative as it explores, explains, applies and exposes the notion of panoptical patriarchy, neonationalist masculinity and the peril of a populist escapism into forms of spatial and mental enclaves. The value of Van der Westhuizen's contribution lies in its incisive analysis of the present-day South Africa.

\section{Acknowledgements Competing interests}

The author declares that she has no financial or personal relationships which may have inappropriately influenced her in writing this article.

\section{References}

Bentham, J., 1995, The panopticon writings, M. Bosovic (ed.), Verso, London.

Dreyer, Y., 2006, 'Heteronormatiwiteit, homofobie en homoseksualiteit - 'n roetekaart vir 'n inklusiewe kerk', HTS Theological Studies 62(2), 445-471. https://doi. org/10.4102/hts.v62i2.375

Dreyer, Y., 2007, 'Hegemony and the internalisation of homophobia caused by heteronormativity', HTS Teologiese Studies/Theological Studies 63(1), 2-18. https://doi.org/10.4102/hts.v63i1.197

Dreyer, Y., 2018, “'Weak, emotional woman should know her place”: Toward authentic life for women', Unpublished keynote address at the annual meeting of the Society for Practical Theology in South Africa, January 2018, Pretoria.

Foucault, M., [1967] 1984, Des Espace Autres ('Of other spaces: Utopias and heterotopias)', transl. J. Miskowiec, Architecture/Mouvement/Continuité October, 1984(5), pp. 46-49, viewed 08 August 2018, from http://web.mit.edu/ allanmc/www/foucault1.pdf

Foucault, M., 1991, 'Panopticism', in P. Rabinow (ed.), The Foucault reader. An introduction to Foucault's thought, pp. 206-213, Penguin, London.

Lefebvre, H., [1974] 1991, The production of space, Blackwell Publishing, Malden, MA.

Van Aarde, A.G., 2012, 'Verset teen mag: Die pelgrim se reis in drie "Sondergut" gelykenisse in Lukas 15 en 16', HTS Teologiese Studies/Theological Studies 68(1), Art. \#1032, 11 pages. https://doi.org/10.4102/hts.v68i1.1032

Van der Westhuizen, C., 2016, 'Afrikaners in post-apartheid South Africa: Inward migration and enclave nationalism', HTS Teologiese Studies/Theological Studies 72(1), a3351. https://doi.org/10.4102/hts.v72i1.3351

Van der Westhuizen, C., 2017, Sitting Pretty: White Afrikaans Women in Postapartheid South Africa, University of KwaZulu-Natal Press, Pietermaritzburg.

Van Wyk, T., 2014, 'Church as heterotopia', HTS Teologiese Studies/Theological Studies 70(1), Art. \#2684, 7 pages. https://doi.org/10.4102/hts.v70i1.2684

Wezner, K., 2012, “'Perhaps I am watching you now”: Panem's Pantopticons', in M.F. Pharr \& L.A. Clark (eds.), Of bread, blood and the Hunger Games: Critical essays on the Suzann Collins Trilogy, pp. 148-158, McFarland \& Company Inc. Publishers, Jefferson, NC. 